Article

\title{
Endophytic Mycobiota of Jingbai Pear Trees in North China
}

\author{
Fei Ren ${ }^{1}\left(\mathbb{D}\right.$, Wei Dong ${ }^{2}$, Hui Sun ${ }^{3}(\mathbb{D})$ and Dong-Hui Yan ${ }^{4, *}$ \\ 1 Experimental Center of Forestry in North China, Chinese Academy of Forestry, Beijing 102300, China; \\ feiren@caf.ac.cn \\ 2 China Electric Power Research Institute, Beijing 100192, China; dongwei3@epri.sgcc.com.cn \\ 3 Collaborative Innovation Center of Sustainable Forestry in Southern China, College of Forestry, \\ Nanjing Forestry University, Nanjing 210037, China; hui.sun@njfu.edu.cn \\ 4 The Key Laboratory of Forest Protection affiliated to State Forestry Administration of China, \\ Institute of Forest Ecology, Environment and Protection, Chinese Academy of Forestry, \\ Beijing 100091, China \\ * Correspondence: yandh@caf.ac.cn; Tel.: +86-010-6288-9521
}

Received: 24 January 2019; Accepted: 12 March 2019; Published: 15 March 2019

check for updates

\begin{abstract}
Endophytic fungi exist in all known plants and play an important role for plant growth and health. As an important forest tree the Jingbai pear (the best quality cultivar of Pyrus ussuriensi Maxim. ex Rupr.) has great ecological as well as economic value in north China. However, the mycobiota of the pear tree is still unknown. In this study, the fungal communities in different organs of the tree and in rhizosphere soils were investigated by Illumina Miseq sequencing of ITS rDNA. For organs, the roots had the highest fungal richness and diversity, while the flowers had the lowest richness and diversity. The results demonstrated that each of the organs investigated harbored a distinctive fungal assemblage. Overall, Ascomycota was the most abundant phyla, followed by Basidiomycota and Zygomycota. Fungal communities from the different soils also differed from each other. The redundancy analysis (RDA) showed that fungal community structure correlated significantly with soil temperature, soil $\mathrm{pH}$, soil nitrogen and soil carbon contents. The results indicate that plant organs, site conditions and soil properties may have important influences on the endophytic fungal community structure associated with Jingbai pear trees.
\end{abstract}

Keywords: endophytic fungi; community diversity and structure; Jingbai pear trees

\section{Introduction}

The plant can be regarded as a holobiont comprising of the host plant and its microbiota with functions, adaptation and interactions between the host and microbiota [1]. Endophytic fungi are an important component of plant microbiota [2-4]. They are ubiquitous and inhabit within the plant organs without causing visible harm to the host $[5,6]$. Endophytic fungi have received extraordinary attention $[4,7,8]$ due to the ability to produce bioactive products [9-11], promote host growth, resist environmental stress [12,13], and even litter decomposition [14]. Many studies have focused on fungal endophytes from agricultural crops, such as wheat, soybeans and tomatoes [15,16], medicinal plants [4,17] and forest trees [18,19]. Although, endophytic fungi of apple and kiwifruit [20,21], wild bananas [22], sour cherry [23] and plums [24] have been reported, information on endophytes from fruit trees is still very limited $[23,25]$. Culture-dependent and culture-independent approaches may provide a different picture of microbial communities and both methods should be used in fungal research $[3,6,26]$. Currently, high-throughput sequencing has the great advantage of generating huge data on species as well as detecting unculturable species at a much lower price, therefore making it easier to extend knowledge of microbial diversity [6,26-28]. 
The Jingbai pear is one of the best quality pears of the Chinese National Products of Geographic Identification brand in Beijing. As an important forest tree, the Jingbai pear has great ecological and economic value in north China [29]. Presently, some pear diseases seriously threaten the yield of the Jingbai pear tree. Chemicals are mainly used to deal with these pathogens, which could cause pollution and harm to people and the environment [29]. Studies on endophytes of Jingbai pear trees might provide novel pathogen biocontrol and growth-promotion agents. However, information on endophytic fungi of Jingbai pear trees is still very little.

A number of driving factors including environmental conditions, the host and microbial genetic background and interactions within plant microbes can influence the endophytic community structure $[4,30]$. Phytosanitary conditions of host plants (health status) also represent a pivotal driving factor of fungal endophytic community structures [18]. The composition of endophytic mycobiota of fruit trees can be diverse depending on the tree species [23]. Liu et al. [31] suggested a genotype-specific influence of different rootstock/scion combinations on apple endophytic microbiota. Another study revealed limited geographic differentiation of fungal communities in apples trees, while a high diversity of fungal community structures was found in blackcurrant from different regions [32]. More research is needed to investigate the endophytic community.

The main aim of this study is to investigate the differences on the endophytic mycobiota composition of different plant organs (flower, leaf, fruit, stem and root). Correlation between the fungal community structure, the sampling sites and the soil properties are also speculated and elucidated. In addition, the study will provide a comprehensive view of the endophytic fungal community of pear trees and useful information for further exploitation and utilization of these communities.

\section{Materials and Methods}

\subsection{Sample Collection}

Sampling sites were located in three main Jingbai pear producing provinces in North China. The first site (site 1) was located in Mentougou District, Beijing $\left(40^{\circ} 0^{\prime} 8.11^{\prime \prime} \mathrm{N}, 116^{\circ} 05^{\prime} 40.10^{\prime \prime} \mathrm{E}\right)$. The second site (site 2) was located in Gu'an, Hebei $\left(39^{\circ} 26^{\prime} 11.52^{\prime \prime} \mathrm{N}, 116^{\circ} 18^{\prime} 33.07^{\prime \prime}\right.$ E). The third site (site 3) was located in Jianchang, Huludao, Liaoning ( $40^{\circ} 52^{\prime} 36.44^{\prime \prime}$ N, $119^{\circ} 50^{\prime} 31.73^{\prime \prime}$ E). Samples were collected from flowers, leaves, stems, roots and soils (rhizosphere soils, $15-25 \mathrm{~cm}$ deep) in mid-April and from fruits in September 2017, according to Ren et al. [33]. In brief, nine Jingbai pear trees, separated at least $200 \mathrm{~m}$ apart, were selected randomly in each site. Organs and soils were evenly mixed and three biological replicates were chosen for each sample. Samples were collected in sterile plastic bags and processed within $24 \mathrm{~h}$. After being washed in tap water, organs were surface-disinfected by washing in sequence with $75 \%$ ethanol for $1 \mathrm{~min}, 2 \%$ sodium hypochlorite for $3 \mathrm{~min}, 75 \%$ ethanol for $1 \mathrm{~min}$, and then rinsed in sterile distilled water for $0.5 \mathrm{~min}$ and dried [33]. Soil $\mathrm{pH}$ was determined with a glass electrode by stirring the soil suspensions in demineralized water with a ratio of $5 \mathrm{~g}$ soil and $25 \mathrm{~mL}$ water, while moisture content was determined by oven drying $\left(105^{\circ} \mathrm{C}\right.$, $24 \mathrm{~h}$ ). The Walkley-Black method [34] and Kjeldahl method [35] were used to test soil carbon (C) and total nitrogen $(\mathrm{N})$ concentration, respectively.

\subsection{DNA Extraction, Amplification of ITS rDNA Region and Illumina Sequencing}

Genomic DNA of the organs was extracted with a standard cetyl-trimethyl ammonium bromide (CTAB) method with modifications as described in Chang et al. [36]. FastDNA ${ }^{\circledR}$ Spin Kit for Soil (MP Biomedicals, Santa Ana, CA, USA) was used to extract DNA from homogenized soil samples. Concentrations of the DNA were measured with a NanoDrop ND-2000 spectrophotometer (Thermo Fisher Scientific, Waltham, MA, USA).

Fungal primers ITS1F (CTTGGTCATTTAGAGGAAGTAA) and ITS2R (GCTGCGTTCTTCATC GATGC) were used to amplify ITS1 region of rDNA [37]. The PCR products were purified and sequenced with Illumina MiSeq. platform at Shanghai Majorbio Science and Technology Ltd (Shanghai, 
China). All sequences were deposited at the Sequence Read Archive (SRA) of the National Center for Biotechnology Information (NCBI) under project accession number SRP154990.

\subsection{Pre-Processing and Analysis of ITS rDNA Sequences}

Raw read quality was pre-processed with FLASH [38] and Trimmomatic [39]. Mothur standard operation pipeline (SOP, v.1.37.6) [40] was used to analyze the data and classify sequences into OTUs (Operational Taxonomic Units) at 97\% similarity against UNITE Database v. 7.2 [41]. Sequence reads were subsampled for each sample with the minimum number of reads among all samples before comparative analysis. The species richness (Sobs), diversity (Invsimpson) and evenness (Simpsoneven) [42] were calculated in Mothur. Data for rarefaction curves were also generated in Mothur. One-way ANOVA (analysis of variance) was used to identify differences in community richness, diversity and evenness, and fungal abundance among organs, the ANOVA assumptions were verified before use and post hoc tests were also carried out with Scheffe and Welch uncorrected (0.95) separately. R language platform [43] was used for analysis and visualization of data sets of the microbial diversity and abundances in different samples (Rarefaction curves, Venn, bar chart, PCoA, RDA, PERMANOVA).

\section{Results}

\subsection{Information on MiSeq Sequencing Data}

In total, 2,075,780 high quality sequences were generated across all samples after sequence denoising and quality filtering. The number of sequences in each sample ranged from 30,345 to 44,599 with an average of 38, $440 \pm 3996$ (mean \pm SD) sequences. The average sequence length was $263 \mathrm{bp}$.

\subsection{Fungal Richness, Diversity and Evenness}

Quality-filtered fungal sequences were clustered into 1856 OTUs (excluding singletons). The roots had the highest fungal richness (159.33) and diversity (8.95), and the flowers had the lowest richness (64.22) and diversity (2.83) (Table 1). The highest evenness of fungal communities was found in leaves (0.07), while the lowest evenness was observed in flowers (0.047) (Table 1). Fungal richness, diversity and evenness of tissues and soils showing statistically significant differences are shown in Supplementary Figure S1 labeled with an asterisk $(*)$. Rarefaction curve showed that the OTUs abundance were saturated in all samples (Supplementary Figure S2).

Table 1. Richness, diversity and evenness indexes of fungal communities (mean \pm SD).

\begin{tabular}{cccc}
\hline Samples & Sobs (Richness) & Invsimpson (Diversity) & Simpsoneven (Evenness) \\
\hline leaf & $109.78 \pm 7.37$ & $5.92 \pm 0.27$ & $0.074 \pm 0.006$ \\
flower & $64.22 \pm 1.55$ & $2.83 \pm 0.08$ & $0.047 \pm 0.002$ \\
fruit & $115.56 \pm 6.03$ & $5.98 \pm 0.35$ & $0.057 \pm 0.003$ \\
stem & $120.00 \pm 6.84$ & $4.58 \pm 0.19$ & $0.048 \pm 0.004$ \\
root & $159.33 \pm 6.27$ & $8.95 \pm 0.54$ & $0.057 \pm 0.003$ \\
soil & $487.44 \pm 15.82$ & $9.95 \pm 1.24$ & $0.018 \pm 0.002$ \\
\hline
\end{tabular}

\subsection{Fungal Community Composition among Different Organs and Soils}

The sequences assigned to fungi kingdom were classified into 6 fungal phyla (excluding unclassified fungi). Ascomycota was the most abundant group (91.2\%) followed by Basidiomycota $(3.6 \%)$ and Zygomycota ( $0.5 \%)$. Chytridiomycota, Rozellomycota and Glomeromycota were much less $(<0.1 \%)$. The abundances of phyla exceeding $1 \%$ in each organ are shown in Figure 1a. Abundance of Zygomycota and Chytridiomycota showed significant differences among all samples, while the abundances of Ascomycota and Basidiomycota did not (Supplementary Figure S3A). Thirteen classes had a relative abundance of more than 1\% (Figure 1b), which include Dothideomycetes, 
Sordariomycetes, Eurotiomycetes, Leotiomycetes, Saccharomycetes, Agaricomycetes, etc. Class Dothideomycetes were predominant in all five organs. However, Sordariomycetes was the most abundant in tree soils. The abundance of Leotiomycetes was much higher in roots. Abundance of 11 classes (including classes mentioned above) showed significant differences among all samples (Supplementary Figure S3B).

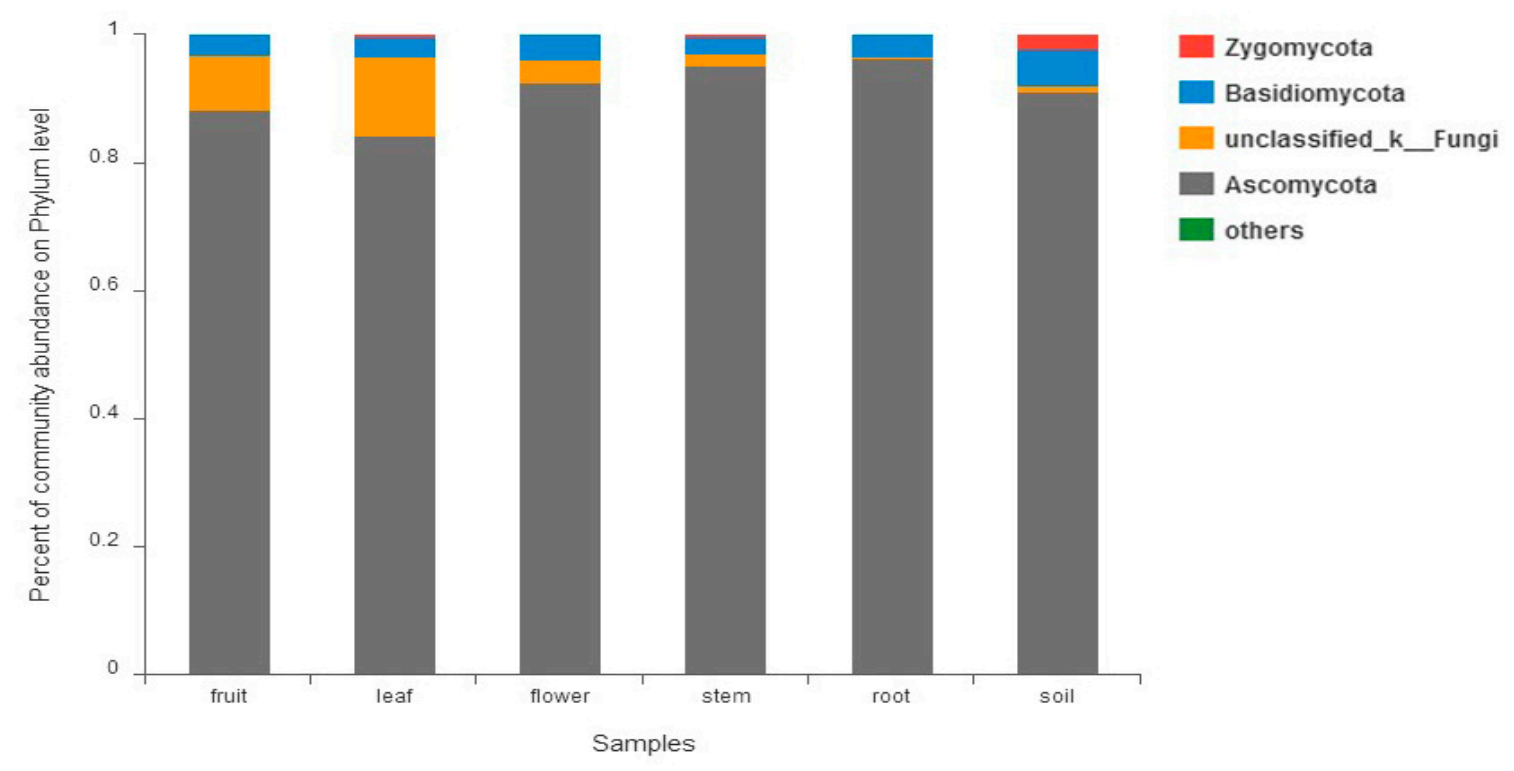

a

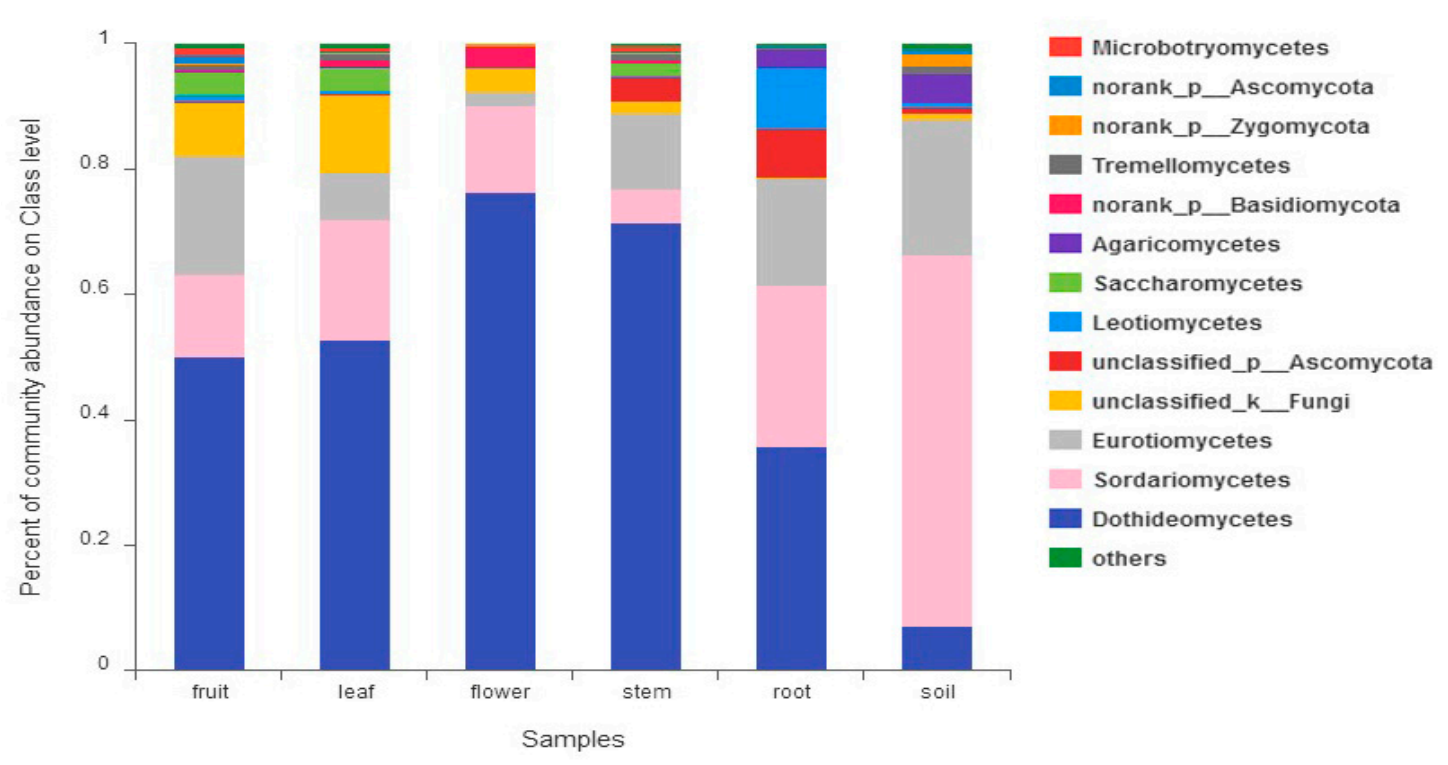

Figure 1. Fungal abundance in different organs and soil: (a) at phylum level; (b) at class level. 


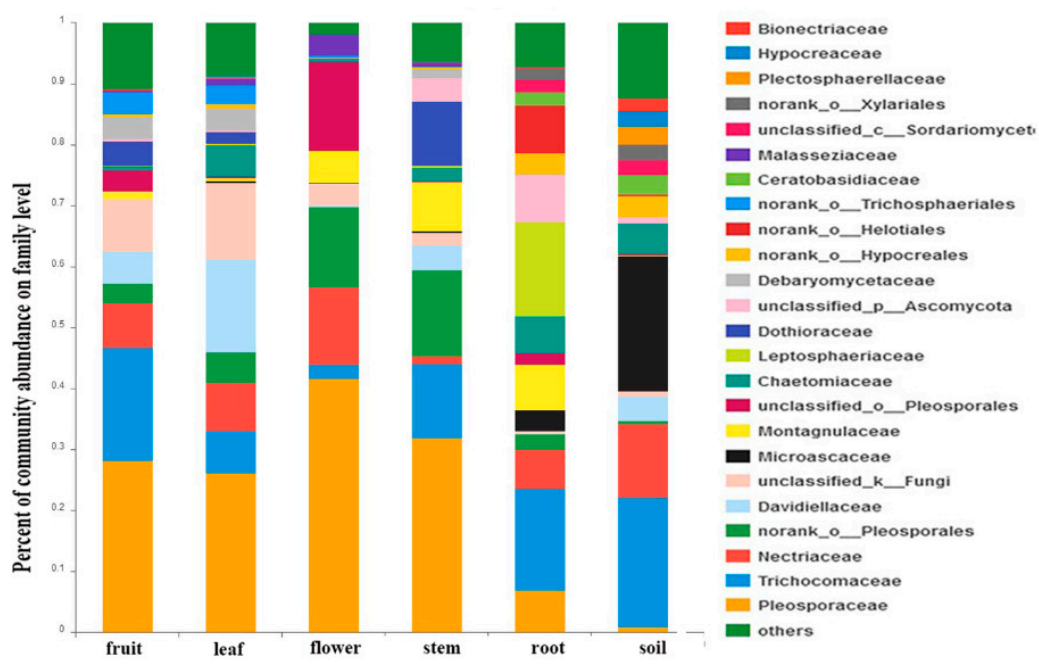

a

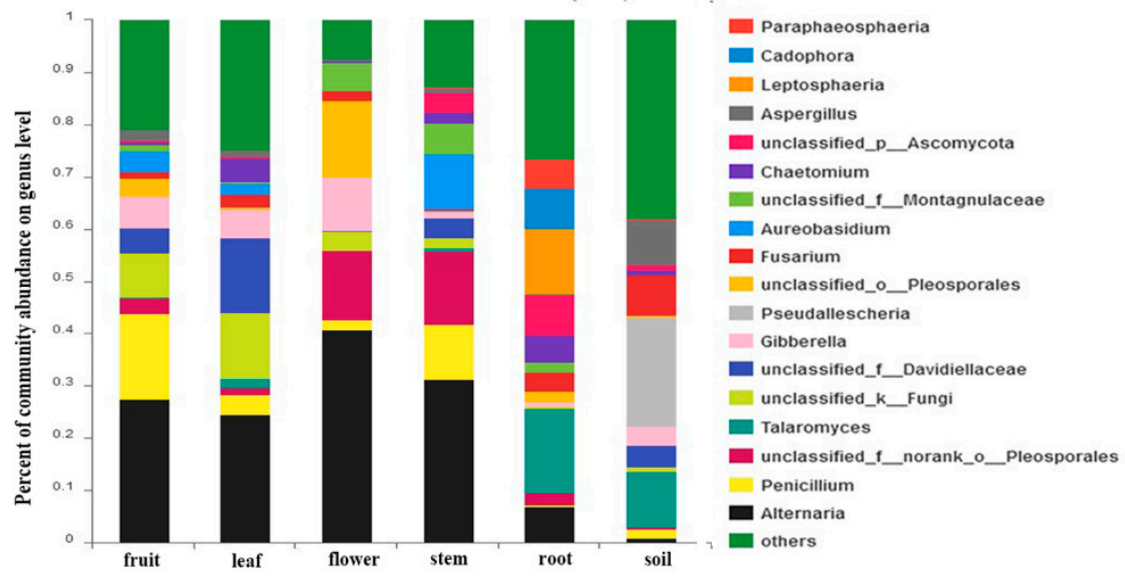

b

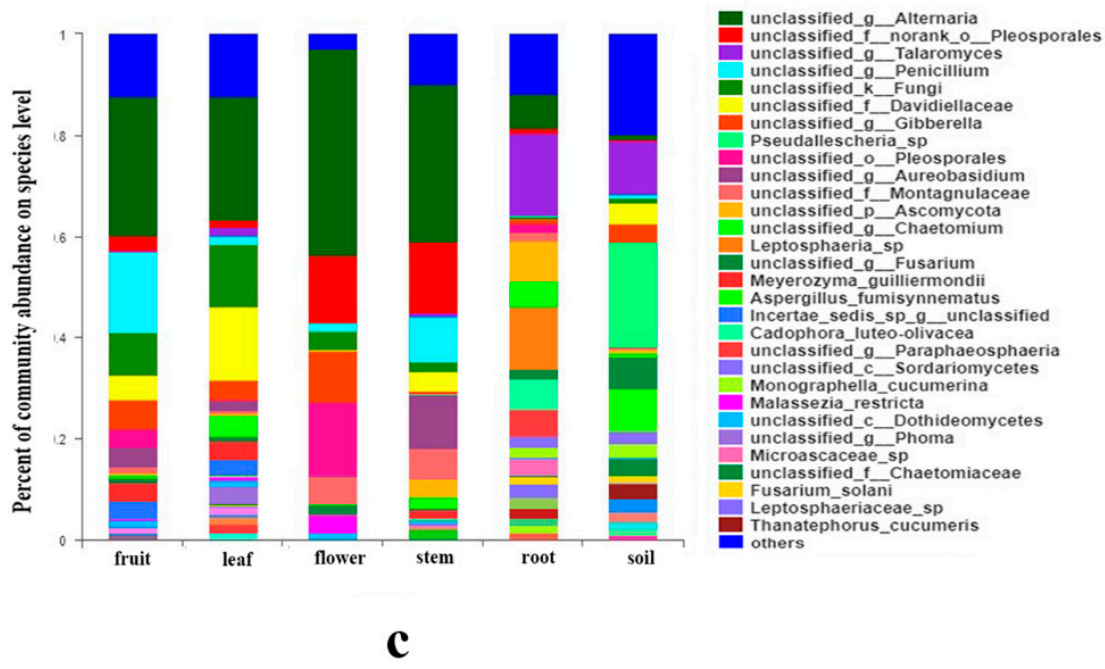

Figure 2. Fungal abundance in different organs and soil: (a) at family level; (b) at genus level; (c) at species level. 
At the family level, abundance of 24 families exceeded 2\% (Figure 2a). Pleosporaceae (Dothideomycetes) were most abundant in fruits, leaves, flowers and stems, while Trichocomaceae (Eurotiomycetes) were richest in roots and soils. A total of 19 fungal genera of fungi had a relative abundance of more than $2 \%$ (Figure $2 b$ ), such as Alternaria, Penicillium, Talaromyces, Gibberella, Pseudallescheria, Fusarium, etc. A few species can be identified, such as Meyerozyma guilliermondii (Wick.) Kurtzman and M. Suzuki, Aspergillus fumisynnematus Y. Horie, Miyaji, Nishim., Taguchi and Udagawa, and Fusarium solani (Mart.) Sacc. Many sequences can be just classified to genus or higher level. The organs and soils sampled shared 59 (3.2\%) of the total 1856 OTUs. The OTUs proportion unique to a certain tissue ranged from $0.9 \%$ (16 OTUs; leaves) to $8.6 \%$ (159 OTUs; stems) (Figure 3). An abundance of 14 families, 12 genera, 12 species and 14 OTUs showed significant differences among organs and soils (Supplementary Figure S3C-F).

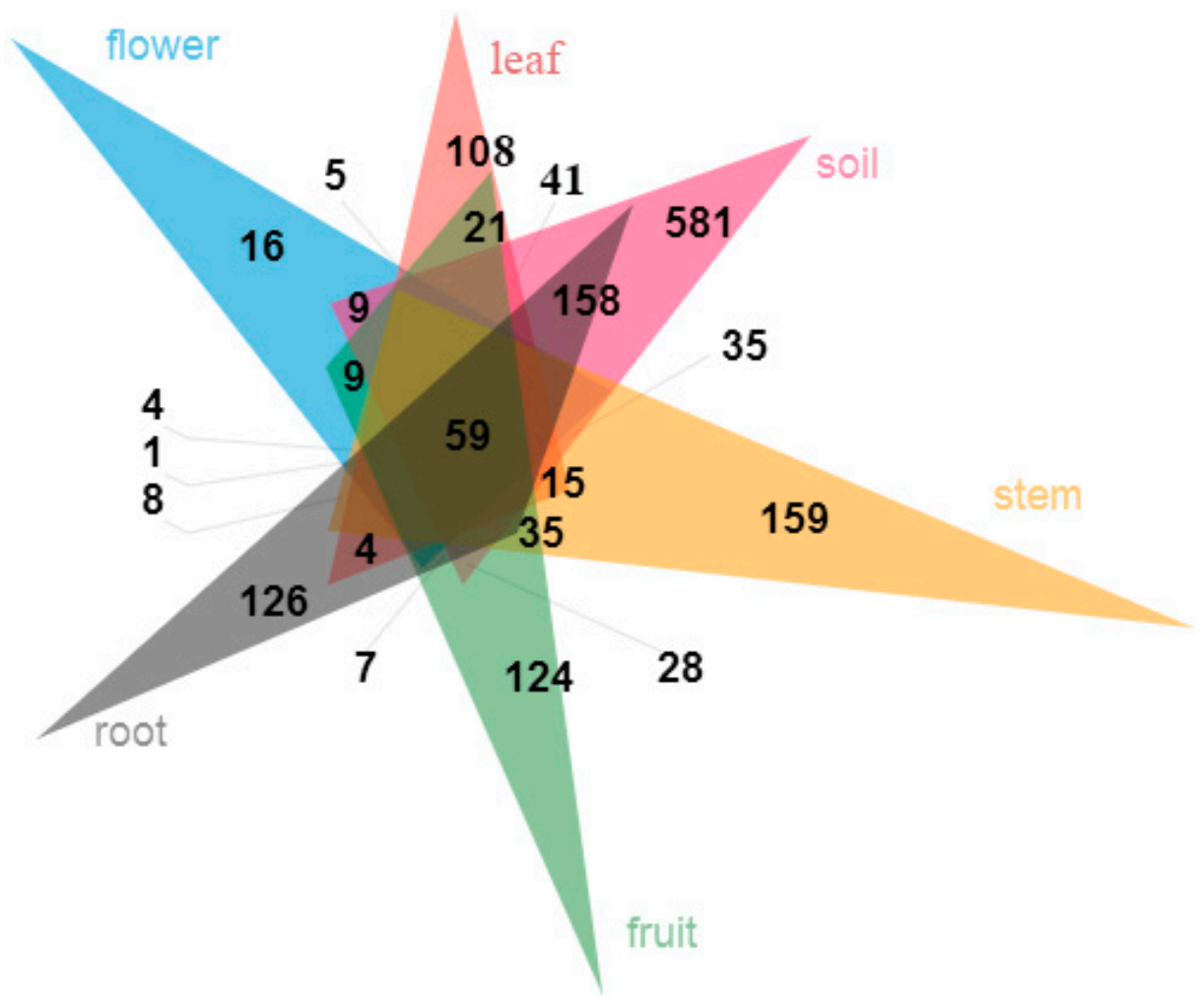

Figure 3. Venn diagram showing shared and unique fungal OTUs in each organ (flower, leaf, fruit, stem, root) and soil.

\subsection{The Relationship between Fungal Community Structure and Organs, Sampling Sites and Soil Properties}

Principal Coordinate Analysis (PCoA) showed that each organ formed individual clusters as well as the soils (Figure 4a). PCoA also illustrated that the three sites formed different fungal clusters (Figure $4 b$ ). A subsequent PERMANOVA test confirmed the significant differences in community structures among the five organs, the soils ( $p<0.05$ in all possible pairs), as well as the three sites $(p<0.05)$.

The RDA tests showed that the fungal community structure was significantly correlated with soil temperature $\left(\mathrm{r}^{2}=0.86, p=0.001\right)$, soil $\mathrm{pH}\left(\mathrm{r}^{2}=0.77, p=0.001\right)$, soil $\mathrm{N}\left(\mathrm{r}^{2}=0.82, p=0.001\right)$ and soil C $\left(\mathrm{r}^{2}=0.75, p=0.001\right)$ (Figure 5). The soil properties of three sites can be found in Ren et al. [33]. Briefly, soil temperature values were $14.2,13.2,11.0\left({ }^{\circ} \mathrm{C}\right)$; $\mathrm{pH}$ were $7.1,7.2,6.8$; soil $\mathrm{N}$ values were 1.6, 1.5, 1.7 (mg/g); soil C values were 13.5, 12.2, $15.3(\mathrm{mg} / \mathrm{g})$ (mean value in Beijing, Hebei, Liaoning, respectively) [33]. 


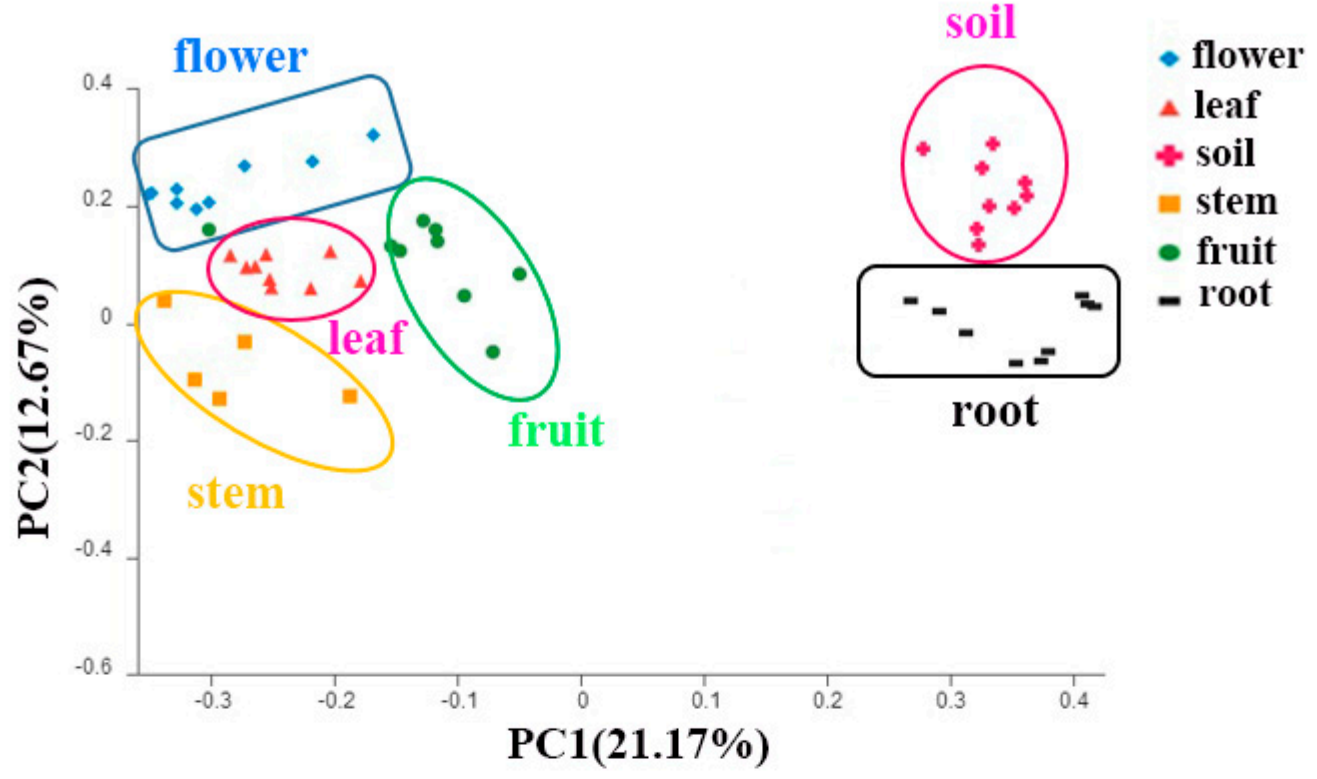

a

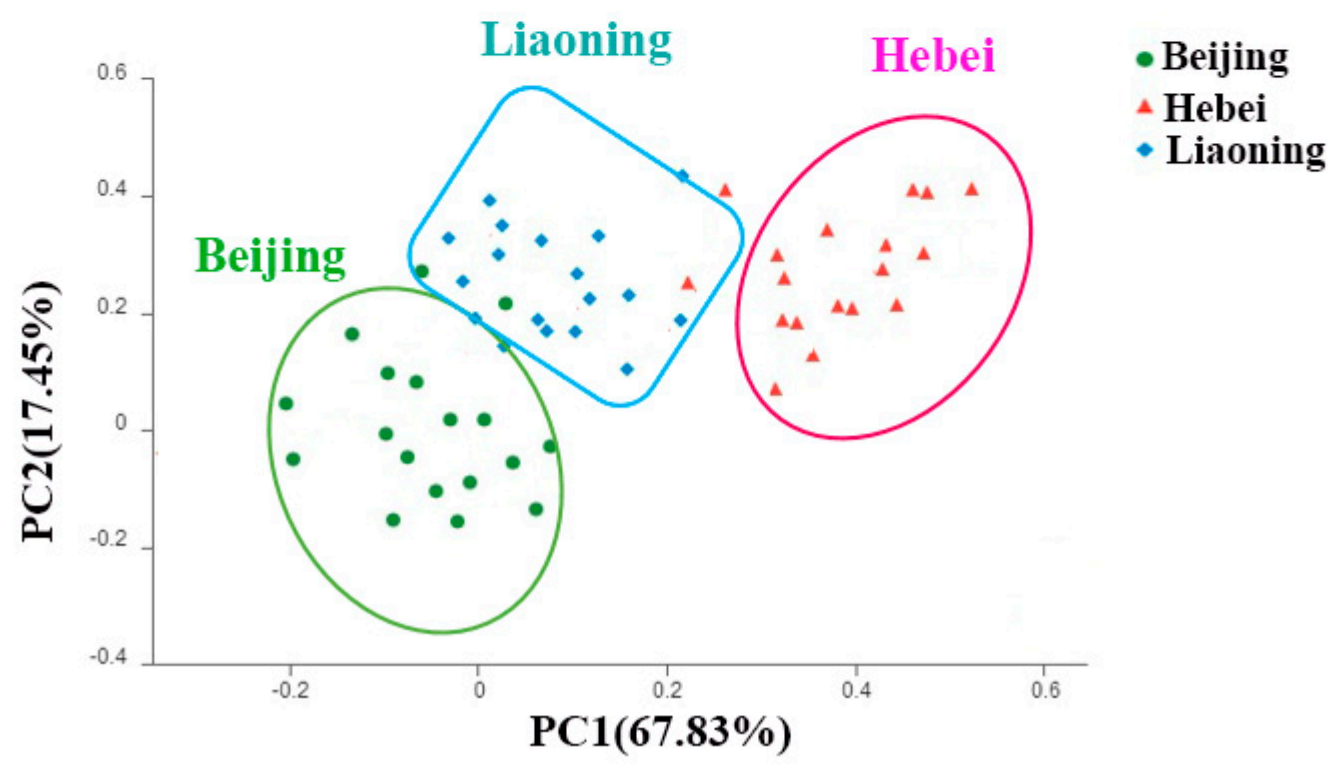

b

Figure 4. Principal coordinates analysis (PCOA) based on the relative abundance of fungal OTUs showing the fungal community structure: (a) in different organs and soil of Jingbai pear trees; (b) in different sites. 


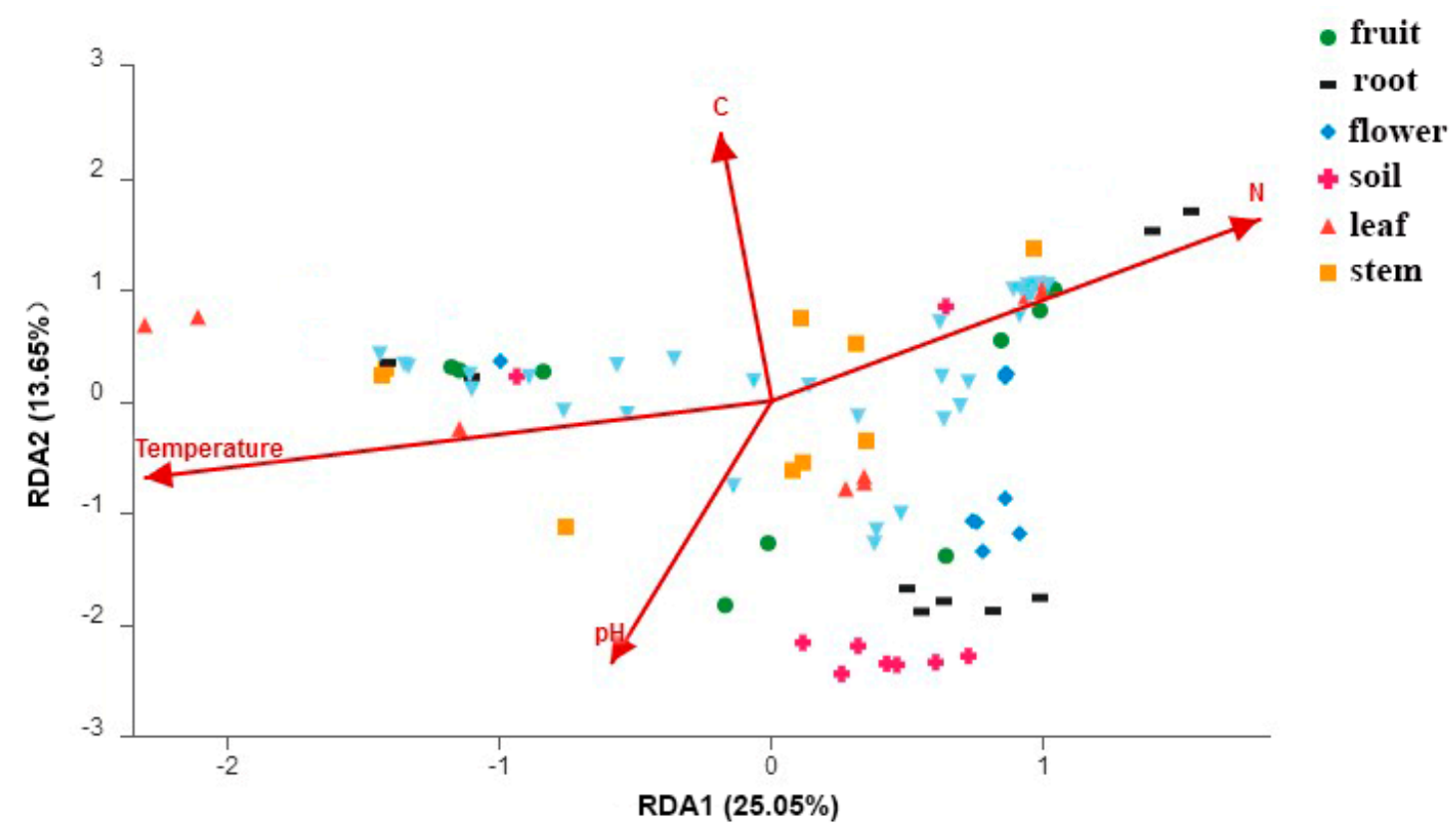

Figure 5. RDA plot showing the correlation between fungal community structure and soil properties.

\section{Discussion}

Although both culture-dependent and culture-independent approaches should be used for microbial studies $[3,26]$, next-generation sequencing technology was mainly adopted in this studyas high-throughput sequencing has the great advantage of generating huge species data and detecting unculturable species at a much lower price. Isolation and isolation-related studies will be carried out in the future. As far as it is known, this is the first implementation of PCR-based Illumina Miseq technology for investigating endophytic mycobiota in Jingbai pear trees. In this study 6 phyla, 28 classes, 90 orders, 208 families, 478 genera, 832 species and 1856 OTUs were identified in the fungi kingdom, providing a comprehensive picture for the unexplored fungal diversity of Jingbai pear trees.

Previous studies have shown that mycobiota mainly consist of Ascomycota and to a lesser extent, Basidiomycota and Zygomycota $[6,18,26,44]$. The fungal communities in our study were also predominated by Ascomycota in all the organs and soils. Class Dothideomycetes was the most abundant in all organs, however, its abundance was much lower in roots and soils than in the other four organs. Dothideomycetes has also been reported as the largest group in Pinus halepensis Mill. [45], Lycopodium annotinum L. and Lycopodium clavatum L. [46], as well as blackcurrant berries in Lithuania [32]. Members of Dothideomycetes include several plant pathogens and the majority are found to be endophytes, or saprobes growing on woody debris, decaying leaves or dung [19,46,47]. The abundance of Sordariomycetes and Leotiomycetes has shown an opposite trend compared to Dothideomycetes. The two classes are sister groups [48]. Members include endophytes, saprobes, coprophilous and fungicolous, and lichenicolous taxa $[49,50]$. The high abundance of Sordariomycetes and Leotiomycetes in the roots of Jingbai pear trees may indicate an active role.

At family level, Pleosporaceae were the most abundant in fruits, leaves, flowers and stems, while Trichocomaceae were the most abundant in roots and soils. Pleosporaceae species were found as endophytes of plants, pathogenic or saprobic on wood, herbaceous stems and leaves [51,52]. Trichocomaceae including members of Aspergillus and Penicillium found in soils as well as plants [53,54]. Alternaria spp. were the most abundant in fruits, leaves, flowers and stems, which were also reported as the most abundant endophytic fungi in fruit cherry [23,55] and apple trees [25]. Alternaria spp. are ubiquitous in the environment and include saprobic, endophytic and pathogenic species associated with a wide variety of substrates [56]. Alternaria spp. can produce highly bioactive metabolites, i.e., one species derived from Morinda officinalis can generate thirteen compounds including 
isobenzofuranone A and indandione B, which have significant inhibitory activities against tumor cell lines [57]. Some species have antimicrobial activities and can be potentially used for biological control of plant diseases [58]. Talaromyces spp. have a wide distribution and some species are involved in leaf litter decomposition [59]. The secondary metabolites and compounds of Talaromyces spp. have attracted great attention, i.e., many strains from mangrove forests show bioactive effects of secondary metabolites (more than 60 compounds identified), particularly cytotoxic/antiproliferative activity against tumor cell lines, antimicrobial effects, and immunosuppressive and enzyme inhibitory aptitudes [60]. In our study, Talaromyces spp. were more abundant in roots and soils. The existence of Alternaria and Talaromyces members were verified. Similarly, the few species identified in the study (Meyerozyma guilliermondii, Aspergillus fumisynnematus, and Fusarium solani) were also cultivated from Jingbai pear organs in this experiment. Meyerozyma guilliermondii has been reported with antifungal, anticancer and phosphate-solubilizing activity [61,62]. Fumimycin produced by Aspergillus fumisynnematus can be a new target in antibacterial, antimalarial and anticancer drug discovery [63]. Bioactive dihydronaphthoquinone derivatives of Fusarium solani exhibit strong cytotoxic activity [64]. For the presence of F. solani within the samples, since ITS region is not a good molecular marker for Fusarium species, the molecular marker Elongation Factor (TEF $1 \alpha$ ) should also be analyzed [65].

The plant habitat is a dynamic environment where many factors can affect the structure of the microbial community [4,30]. Previous studies have shown that different plant organs host a different fungal community $[18,27,32]$. This was verified using a survey that found fungal community structures differed significantly among five organs, since each organ forms a distinctive microenvironment. It has been reported that individual microbiota of compartments consist of a selective gradient from soil, exterior root, rhizoplane, interior roots and other endosphere compartments [6]. In this study, soil and root were found to have the highest fungal richness and diversity. The fungal community in roots and soils demonstrated more similarities when compared with other organs (leaf, flower, fruit and stem), this may be due to spatially distance. Tree conditions (phytosanitary health status) can also be an important factor of fungal endophytic community structures [18]. For Scots pine trees, declining trees were found to harbor a higher number of taxa and were characterized by higher colonization frequencies than healthy-looking trees. Fungal assemblages are significantly affected by the degree of decline of trees [18] and studies on this aspect should be considered in the future.

The results demonstrated that three geographically different sites harbored a unique fungal community. Several studies have reported that site conditions can influence a fungal community $[4,66]$. For fruit trees, there are fewer studies concerning the influence of sites [32]. Blackcurrant from different regions had different fungal communities [32]. Regional effect was also found in grape wine microbial at different vineyards $[67,68]$. Endophytic fungi from medicinal plants in different sites may even affect the quality and effects of medicines [4]. Therefore, geographical locations must be a very important environmental effector.

Fungal community structures were significantly correlated with soil properties-soil temperature, $\mathrm{pH}, \mathrm{N}$ and $\mathrm{C}$, indicating soil may have an influence on the fungal community structure associated with Jingbai pear trees. Plants and soils have a very close mutual relationship. A plant can affect soil organic matter, soil nutrient availability and the composition of soil microbial communities. The influences on soil properties result in net positive or negative feedback effects, which influence plant and community composition [69], for example, soil type and properties may alter root development and root exudation [70]. Endophytic communities live and coevolve with trees for a long time, therefore the structure can be correlated with soil properties [6,69]. In a recent study, the endophytic bacterial communities associated with Jingbai pear trees also differed significantly among different organs and soils, and the bacterial community structure related significantly to soil properties [33]. These findings are consistent with the results of this study. 


\section{Conclusions}

Each organ investigated (flower, leaf, fruit, stem and root) in this study harbored a unique fungal assemblage. Ascomycota was the most abundant phylum, followed by Basidiomycota and Zygomycota. As to the correlation between fungal community structures, the sampling sites and soil properties, the fungal communities from the different sites (soils) differed from each other. The fungal community structure remarkably correlated with soil temperature, soil $\mathrm{pH}$, soil nitrogen and soil carbon contents. These results indicate that plant organs, sampling sites and soil properties may exert influence on the endophytic microbial community structure associated with Jingbai pear trees. The isolation and cultivation of core potential endophytic fungal strains with a growth-promoting effect and pathogen resistance, as well as ecological and functional roles, will require further study.

Supplementary Materials: The following are available online at http:/ /www.mdpi.com/1999-4907/10/3/260/s1. Figure S1. Statistically significant differences in the fungal species richness (A), diversity (B) and evenness (C) of the samples, ${ }^{*} 0.01<p \leq 0.05,{ }^{* *} 0.001<p \leq 0.01,{ }^{* * *} p \leq 0.001$. Figure S2. Rarefaction curves of all the samples. All the samples are saturated for further study. Figure S3. Significantly different taxa among samples. (A) at phylum level, (B) at class level, (C) at family level, (D) at genus level, (E) at species level, (F) at OTU level.

Author Contributions: F.R., H.S., D.-H.Y. conceived the study and contributed in the experimental design of the study; F.R., W.D. and D.-H.Y. collected the samples; F.R. conducted the experiment; F.R., W.D. performed the statistical analysis; F.R. wrote the first draft of the manuscript; all authors contributed to manuscript revision and approved the submitted version.

Funding: This research was funded by the Fundamental Research Funds for the Central Non-profit Research Institution of Chinese Academy of Forestry (project CAFYBB2017MA019).

Acknowledgments: Hai Yu is acknowledged for providing support and help in collecting samples.

Ethics: The samples in the study were collected on private land and the owners gave full permission to conduct the study on the sites. The experimental materials did not involve any humans or animals.

Conflicts of Interest: The authors declare no conflict of interest.

\section{References}

1. Vandenkoornhuyse, P.; Quaiser, A.; Duhamel, M.; Le Van, A.; Dufresne, A. The importance of the microbiome of the plant holobiont. New Phytol. 2015, 206, 1196-1206. [CrossRef] [PubMed]

2. Petrini, O.; Stone, J.; Carroll, F.E. Endophytic fungi in evergreen shrubs in western Oregon: A preliminary study. Can. J. Bot. 1982, 60, 789-796. [CrossRef]

3. Sun, X.; Guo, L.D.; Hyde, K.D. Community composition of endophytic fungi in Acer truncatum and their role in decomposition. Fungal Divers. 2011, 47, 85-95. [CrossRef]

4. Jia, M.; Chen, L.; Xin, H.L.; Zheng, C.J.; Rahman, K.; Han, T.; Qin, L.P. A friendly relationship between endophytic fungi and medicinal plants: A systematic review. Front. Microbiol. 2016, 7, 906. [CrossRef] [PubMed]

5. Azevedo, J.L.; Maccheroni, W.; Pereira, J.A.; Araujo, W.L. Endophytic microorganisms: A review on insect control and recent advances on tropical plants. Electron. J. Biotechnol. 2000, 3, 15-16. [CrossRef]

6. Muller, D.B.; Vogel, C.; Bai, Y.; Vorholt, J.A. The plant microbiota: Systems-level insights and perspectives. Annu. Rev. Genet. 2016, 50, 211-234. [CrossRef]

7. Photita, W.; Lumyong, S.; Lumyong, P.; Hyde, K.D. Endophytic fungi of wild banana (Musa acuminata) at doi Suthep Pui National Park, Thailand. Mycol. Res. 2001, 105, 1508-1513. [CrossRef]

8. Porras-Alfaro, A.; Bayman, P. Hidden fungi, emergent properties: Endophytes and microbiomes. Annu. Rev. Phytopathol. 2011, 49, 291-315. [CrossRef]

9. Xu, J.; Ebada, S.S.; Proksch, P. Pestalotiopsis a highly creative genus: Chemistry and bioactivity of secondary metabolites. Fungal Divers. 2010, 44, 15-31. [CrossRef]

10. Tejesvi, M.V.; Kajula, M.; Mattila, S.; Pirttilä, A.M. Bioactivity and genetic diversity of endophytic fungi in Rhododendron tomentosum Harmaja. Fungal Divers. 2011, 47, 97-107. [CrossRef]

11. Chen, L.; Zhang, Q.Y.; Jia, M.; Ming, Q.L.; Yue, W.; Rahman, K.; Han, T. Endophytic fungi with antitumor activities: Their occurrence and anticancer compounds. Crit. Rev. Microbiol. 2016, 42, 454-473. [CrossRef] [PubMed] 
12. Saikkonen, K.; Saari, S.; Helander, M. Defensive mutualism between plants and endophytic fungi? Fungal Divers. 2010, 41, 101-113. [CrossRef]

13. Yuan, Y.; Feng, H.; Wang, L.; Li, Z.; Shi, Y.; Zhao, L.; Zhu, H. Potential of endophytic fungi isolated from cotton roots for biological control against verticillium wilt disease. PLoS ONE 2017, 12, e0170557. [CrossRef] [PubMed]

14. Purahong, W.; Hyde, K.D. Effects of fungal endophytes on grass and non-grass litter decomposition rates. Fungal Divers. 2011, 47, 1-7. [CrossRef]

15. Larrán, S.; Mónaco, C. Status and progress of research in endophytes from agricultural crops in Argentina. In Management of Fungal Plant Pathogens; Arya, A., Perello, A.E., Eds.; CAB International: Cambridge, UK, 2010; Chapter 12; p. 149.

16. Russo, M.L.; Pelizza, S.A.; Cabello, M.N.; Stenglein, S.A.; Vianna, M.F.; Scorsetti, A.C. Endophytic fungi from selected varieties of soybean (Glycine max L. Merr.) and corn (Zea mays L.) grown in an agricultural area of Argentina. Revista Argentina de Microbiología 2016, 48, 154-160. [CrossRef]

17. Bezerra, J.D.; Nascimento, C.C.; Barbosa, R.D.N.; da Silva, D.C.; Svedese, V.M.; Silva-Nogueira, E.B.; Souza-Motta, C.M. Endophytic fungi from medicinal plant Bauhinia forficata: Diversity and biotechnological potential. Braz. J. Microbiol. 2015, 46, 49-57. [CrossRef]

18. Giordano, L.; Gonthier, P.; Varese, G.C.; Miserere, L.; Nicolotti, G. Mycobiota inhabiting sapwood of healthy and declining Scots pine (Pinus sylvestris L.) trees in the Alps. Fungal Divers. 2009, 38, 69-83.

19. Kovalchuk, A.; Mukrimin, M.; Zeng, Z.; Raffaello, T.; Liu, M.X.; Kasanen, R.; Sun, H.; Asiegbu, F.O. Mycobiome analysis of asymptomatic and symptomatic Norway spruce trees naturally infected by the conifer pathogens Heterobasidion spp. Environ. Microbiol. Rep. 2018, 10, 532-541. [CrossRef]

20. Johnston, P.R. Endophytes of apple and kiwifruit. In Proceedings of the 47th New Zealand Plant Protection Conference, Waitangi, New Zealand, 9-11 August 1994; New Zealand Plant Protection Society Inc.: Rotorua, New Zealand, 1994; p. 353.

21. Camatti-Sartori, V.; da Silva-Ribeiro, R.T.; Valdebenito-Sanhueza, R.M.; Pagnocca, F.C.; Echeverrigaray, S.; Azevedo, J.L. Endophytic yeasts and filamentous fungi associated with southern Brazilian apple (Malus domestica) orchards subjected to conventional, integrated or organic cultivation. J. Basic Microb. 2005, 45, 397-402. [CrossRef]

22. Photita, W.; Lumyong, S.; Lumyong, P.; McKenzie, E.H.C.; Hyde, K.D. Are some endophytes of Musa acuminata latent pathogens? Fungal Divers. 2004, 16, 131-140.

23. Hortova, B.; Novotny, D. Endophytic fungi in branches of sour cherry trees: A preliminary study. Czech Mycol. 2011, 63, 77-82.

24. Janisiewicz, W.J.; Jurick, W.M.; Peter, K.A.; Kurtzman, C.P.; Buyer, J.S. Yeasts associated with plums and their potential for controlling brown rot after harvest. Yeast 2014, 31, 207-218. [CrossRef] [PubMed]

25. Novotny, D. Studium endofytickych hub zemedelsky vyznamnch rostlin. Sbornik prispevku z workshopu Micromyco 2007, 4, 9 .

26. Sun, X.; Guo, L.D. Endophytic fungal diversity: Review of traditional and molecular techniques. Mycology 2012, 3, 65-76.

27. Pinto, C.; Pinho, D.; Sousa, S.; Pinheiro, M.; Egas, C.; Gomes, A.C. Unravelling the diversity of grapevine microbiome. PLoS ONE 2014, 9, e85622. [CrossRef] [PubMed]

28. Berg, G.; Rybakova, D.; Grube, M.; Koberl, M. The plant microbiome explored: Implications for experimental botany. J. Exp. Bot. 2016, 67, 995-1002. [CrossRef]

29. Dong, G.L. Cultivation Technology of Jing Bai Pear; Capital Normal University Press: Beijing, China, 2010; pp. 1-187. (In Chinese)

30. Hardoim, P.R.; van Overbeek, L.S.; Berg, G.; Pirttila, A.M.; Compant, S.; Campisano, A.; Döring, M.; Sessitsch, A. The hidden world within plants: Ecological and evolutionary considerations for defining functioning of microbial endophytes. Microbiol. Mol. Biol. Rev. 2015, 79, 293-320. [CrossRef] [PubMed]

31. Liu, J.; Abdelfattah, A.; Norelli, J.; Burchard, E.; Schena, L.; Droby, S.; Wisniewski, M. Apple endophytic microbiota of different rootstock/scion combinations suggests a genotype-specific influence. Microbiome 2018, 6, 18. [CrossRef] [PubMed]

32. Vepštaitè-Monstavičè, I.; Lukša, J.; Stanevičienè, R.; Strazdaitė-Žielienè, Ž.; Yurchenko, V.; Serva, S.; Servienè, E. Distribution of apple and blackcurrant microbiota in Lithuania and the Czech Republic. Microbiol. Res. 2018, 206, 1-8. [CrossRef] 
33. Ren, F.; Dong, W.; Yan, D.H. Endophytic bacterial communities of Jingbai Pear trees in north China analyzed with Illumina sequencing of $16 \mathrm{~S}$ rDNA. Arch. Microbiol. 2018. [CrossRef] [PubMed]

34. Nelson, D.W.; Sommers, L.E. Total carbon, organic carbon, and organic matter. In Methods of Soil Analysis Part 3: Chemical Methods (Methodsofsoilan3); Sparks, D.L., Ed.; Soil Science Society of America Publisher Inc.: Madison, WI, USA, 1996; pp. 961-1010.

35. Bremner, J.M. Total Nitrogen. In Methods of Soil Analysis Part 2: Chemical and Microbial Properties; Black, C.A., Ed.; American Society of Agronomy Publisher Inc.: Madison, WI, USA, 1965; pp. 1049-1178.

36. Chang, S.; Puryear, J.; Cairney, J. A simple and efficient method for isolating RNA from pine trees. Plant. Mol. Biol. Rep. 1993, 11, 113-116. [CrossRef]

37. Lanzén, A.; Epelde, L.; Blanco, F.; Martín, I.; Artetxe, U.; Garbisuet, C. Multi-targeted metagenetic analysis of the influence of climate and environmental parameters on soil microbial communities along an elevational gradient. Sci. Rep. 2016, 6, e28257. [CrossRef] [PubMed]

38. Magoč, T.; Salzberg, S.L. FLASH: Fast length adjustment of short reads to improve genome assemblies. Bioinformatics 2011, 27, 2957-2963. [CrossRef] [PubMed]

39. Bolger, A.M.; Lohse, M.; Usadel, B. Trimmomatic: A flexible trimmer for Illumina sequence data. Bioinformatics 2014, 30, 2114-2120. [CrossRef] [PubMed]

40. Schloss, P.D.; Gevers, D.; Westcott, S.L. Reducing the effects of PCR amplification and sequencing artifacts on 16S rRNA-based studies. PLoS ONE 2011, 6, e27310. [CrossRef] [PubMed]

41. UNITE Community. UNITE Mothur Release. Version 01.12.2017. UNITE Community 2017. [CrossRef]

42. Mothur Calculators. Available online: https://www.mothur.org/wiki/Calculators (accessed on 1 December 2018).

43. R Core Team. R: A Language and environment for Statistical Computing; R Foundation for Statistical Computing: Vienna, Austria, 2013.

44. Sinclair, J.B.; Cerkauskas, R.F. Latent infection vs. endophytic colonization by fungi. In Endophytic Fungi in Grasses and Woody Plants: Systematics, Ecology and Evolution; APS Press: St Paul, MN, USA, 1996; pp. 3-29.

45. Botella, L.; Diez, J.J. Phylogenic diversity of fungal endophytes in Spanish stands of Pinus halepensis. Fungal Divers. 2011, 47, 9-18. [CrossRef]

46. Pawłowska, J.; Wilk, M.; Śliwińska-Wyrzychowska, A.; Mętrak, M.; Wrzosek, M. The diversity of endophytic fungi in the above-ground tissue of two Lycopodium species in Poland. Symbiosis 2014, 63, 87-97. [CrossRef]

47. Nelsen, M.P.; Lücking, R.; Grube, M.; Mbatchou, J.S.; Muggia, L.; Plata, E.R.; Lumbsch, H.T. Unravelling the phylogenetic relationships of lichenised fungi in Dothideomyceta. Stud. Mycol. 2009, 64, 135-144. [CrossRef]

48. Robbertse, B.; Reeves, J.B.; Schoch, C.L.; Spatafora, J.W. A phylogenomic analysis of the Ascomycota. Fungal Genet. Biol. 2006, 43, 715-725. [CrossRef]

49. Higgins, K.L.; Arnold, A.E.; Miadlikowska, J.; Sarvate, S.D.; Lutzoni, F. Phylogenetic relationships, host affinity, and geographic structure of boreal and arctic endophytes from three major plant lineages. Mol. Phylogenet. Evol. 2007, 42, 543-555. [CrossRef]

50. Maharachchikumbura, S.S.; Hyde, K.D.; Jones, E.G.; McKenzie, E.H.; Huang, S.K.; Abdel-Wahab, M.A.; Hongsanan, S. Towards a natural classification and backbone tree for Sordariomycetes. Fungal Divers. 2015, 72, 199-301. [CrossRef]

51. Abutaha, N.; Mashaly, A.M.; Al-Mekhlafi, F.A.; Farooq, M.; Al-shami, M.; Wadaan, M.A. Larvicidal activity of endophytic fungal extract of Cochliobolus spicifer (Pleosporales: Pleosporaceae) on Aedes caspius and Culex pipiens (Diptera: Culicidae). Appl. Entomol. Zool. 2015, 50, 405-414. [CrossRef]

52. Ariyawansa, H.A.; Thambugala, K.M.; Manamgoda, D.S.; Jayawardena, R.; Camporesi, E.; Boonmee, S.; Chukeatirote, E. Towards a natural classification and backbone tree for Pleosporaceae. Fungal Divers. 2015, 71, 85-139. [CrossRef]

53. McGee, P.A.; Markovina, A.L.; Jeong, G.C.; Cooper, E.D. Trichocomaceae in bark survive high temperatures and fire. FEMS Microbiol. Ecol. 2006, 56, 365-371. [CrossRef]

54. Leite, D.P.J.; Yamamoto, A.C.; Amadio, J.V.; Martins, E.R.; do Santos, F.A.; Simões Sde, A.; Hahn, R.C. Trichocomaceae: Biodiversity of Aspergillus spp. and Penicillium spp. residing in libraries. J. Infect. Dev. Ctries. 2012, 6, 734-743.

55. Dugan, F.M.; Roberts, R.G. Etiology of preharvest colonization of Bing cherry fruit by fungi. Phytopathology 1994, 84, 1031-1036. [CrossRef]

56. Woudenberg, J.H.C.; Groenewald, J.Z.; Binder, M.; Crous, P.W. Alternaria redefined. Stud. Mycol. 2013, 75, 171-212. [CrossRef] 
57. Wang, Y.; Liu, H.X.; Chen, Y.C.; Sun, Z.H.; Li, H.H.; Li, S.N.; Yan, M.L.; Zhang, W.M. Two new metabolites from the endophytic fungus Alternaria sp. A744 derived from Morinda officinalis. Molecules 2017, 22, 765. [CrossRef]

58. Xiang, L.; Gong, S.; Yang, L.; Hao, J.; Xue, M.; Zeng, F.; Yu, D. Biocontrol potential of endophytic fungi in medicinal plants from Wuhan Botanical Garden in China. Biol. Control 2016, 94, 47-55. [CrossRef]

59. Yilmaz, N.; Visagie, C.M.; Frisvad, J.C.; Houbraken, J.; Jacobs, K.; Samson, R.A. Taxonomic re-evaluation of species in Talaromyces section Islandici, using a polyphasic approach. Persoonia 2016, 36, 37-56. [CrossRef]

60. Nicoletti, R.; Salvatore, M.M.; Andolfi, A. Secondary Metabolites of Mangrove-Associated Strains of Talaromyces. Mar. Drugs 2018, 16, 12. [CrossRef]

61. Coda, R.; Rizzello, C.G.; Cagno, R.D.; Trani, A.; Cardinali, G.; Gobbetti, M. Antifungal activity of Meyerozyma guilliermondii: Identification of active compounds synthesized during dough fermentation and their effect on long-term storage of wheat bread. Food Microbiol. 2013, 33, 243-251. [CrossRef]

62. Nakayan, P.; Hameed, A.; Singh, S.; Young, L.S.; Hung, M.H.; Young, C.C. Phosphate-solubilizing soil yeast Meyerozyma guilliermondii $\mathrm{cc} 1$ improves maize (Zea mays L.) productivity and minimizes requisite chemical fertilization. Plant Soil 2013, 373, 301-315. [CrossRef]

63. Kwon, Y.J.; Sohn, M.J.; Zheng, C.J.; Kim, W.G. Fumimycin: A peptide deformylase inhibitor with an unusual skeleton produced by Aspergillus fumisynnematus. Org. Lett. 2007, 9, 2449-2451. [CrossRef]

64. Takemoto, K.; Kamisuki, S.; Chia, P.T.; Kuriyama, I.; Mizushina, Y.; Sugawara, F. Bioactive dihydronaphthoquinone derivatives from Fusarium solani. J. Nat. Prod. 2014, 77, 1992-1996. [CrossRef]

65. Bezos, D.; Martínez-Álvarez, P.; Sanz-Ros, A.V.; MartínGarcía, J.; Fernandez, M.M.; Diez, J.J. Fungal Communities Associated with BarkBeetles in Pinus radiata Plantations in Northern Spain Affected by Pine Pitch Canker, with Special Focus on Fusarium Species. Forests 2018, 9, 698. [CrossRef]

66. Martín-Pinto, P.; Pajares, J.A.; Nanos, N.; Diez, J.J. Site and seasonal influences on the fungal community on leaves and stems of Pinus and Quercus seedlings in forest nurseries. Sydowia 2004, 56, 243-257.

67. Pinto, C.; Pinho, D.; Cardoso, R.; Custodio, V.; Fernandes, J.; Sousa, S.; Pinheiro, M.; Egas, C.; Gomes, A.C. Wine fermentation microbiome: A landscape from different Portuguese wine appellations. Front. Microbiol. 2015, 6, 905. [CrossRef]

68. Bokulich, N.A.; Thorngate, J.H.; Richardson, P.M.; Mills, D.A. Microbial biogeography of wine grapes is conditioned by cultivar, vintage, and climate. Proc. Natl. Acad. Sci. USA 2014, 111, E139-E148. [CrossRef]

69. Bezemer, T.M.; Lawson, C.S.; Hedlund, K.; Edwards, A.R.; Brook, A.J.; Igual, J.M.; Mortimer, S.R.; Van Der Putten, W.H. Plant species and functional group effects on abiotic and microbial soil properties and plant-soil feedback responses in two grasslands. J. Ecol. 2006, 94, 893-904. [CrossRef]

70. Neumann, G.; Bott, S.; Ohler, M.; Mock, H.P.; Lippmann, R.; Grosch, R.; Smalla, K. Root exudation and root development of lettuce (Lactuca sativa L. cv. Tizian) as affected by different soils. Front. Microbiol. 2014, 5, 2. [CrossRef]

(C) 2019 by the authors. Licensee MDPI, Basel, Switzerland. This article is an open access article distributed under the terms and conditions of the Creative Commons Attribution (CC BY) license (http:/ / creativecommons.org/licenses/by/4.0/). 